\title{
Visegrad Group from the Perspective of Investment's Taxation and the Role of Depreciation Methods
}

\author{
Vít JEDLIČKA ${ }^{1}$ and Jaroslav KOVÁRNÍK ${ }^{2, *}$ \\ 1 University of Pardubice, Pardubice, Czech Republic; vit.jedlicka@upce.cz \\ 2 University of Hradec Králové, Hradec Králové, Czech Republic; jaroslav.kovarnik@uhk.cz \\ * Correspondence: jaroslav.kovarnik@uhk.cz
}

\begin{abstract}
Taxation have significant impact on selection of investments' location. Visegrad Group countries are from the same region and they compete for similar segment of investors and this causes tax competition between them. The largest investors in this area are companies from the Netherlands, Luxembourg, Germany and Austria. Investors prefer lower tax burden therefore the position of these countries can differ based on the tax conditions. Tax burden within this study is measured by Devereux and Griffith's effective average tax rate (EATR) for cross-border investment. The EATRs in countries from Visegrad Group are generally relatively close expect the situation of the investment in Hungary, which provides the best conditions thanks to the lowest statutory corporate tax rate. Tax treaties and depreciation methods cause other differences between the tax burdens. Especially, the investors from Austria have disadvantage for cross-border payments from Visegrad countries, except payments from the Czech Republic. The situation of the Czech Republic demonstrates the importance of depreciation methods, which have significant role in the case of closer statutory corporate tax rates and similar tax treaties. Use of accelerated depreciation in the Czech Republic brings about half percentage lower effective tax rate than the standard depreciation method.
\end{abstract}

Keywords: tax competition; tax planning; foreign direct investment; effective tax rate

JEL Classification: H25; H26; M29

\section{Introduction}

Tax legislation belongs to one of the most important attributes of business environment. Companies' business activities are affected by level of taxation and enormously high tax burden can discourage companies from realizing the investment. Overall, managers of companies tend to avoid paying taxes to increase the profits of investments. On the other hand, government's role is, at the first sight, the opposite. Governments want to collect taxes as much as it is possible in particular situation because taxes are the basic revenue, by which functioning of country is financed. The term situation has very broad scope. One limitation is described by Laffer curve: increase of tax rate does not automatically result in higher tax revenues. Current economic situation is the second important issue, which influences the form of legislation. The last basic problem, which governments solve, is economic growth. Very high tax burden reduces economic activity and profitability of businesses. Companies can stop doing their business or use other countries to reduce their tax liabilities. This can be made by simple relocation of their activities or more sophisticated profit shifting. Nowadays, use of tax legislation of several countries is frequently discussed topic.

Depreciation method is one of the most important aspects which influences overall tax burden. Therefore ability of more beneficial depreciation method is another issue which can improve overall attractiveness of particular location. When it comes to foreign direct investment (FDI), the depreciation methods can have a decisive effect on the location selection because investments are connected with large amount of assets. This paper deals with taxation of the investment and is also focused on the role of the tax depreciation. In the first part of it, there is literature review with statement of a problem. Following part is dedicated to the methods used with the paper. Results are shown in the third chapter and are followed by discussion and conclusion. 
The situation of FDI in new EU countries and other transition economies, was studied by Mádr and Kouba (2014). They focused on political instability in selected countries and its effect on inflow of FDI. They used two regression analyses with the total tax rate as an explanatory variable. They found that the dependence of political instability on FDI is not provable (Mádr and Kouba 2014). On the other hand, results show that some of the variables can have effect on the FDI, especially presence of onecolor government can have positive effect on FDI inflows. The situation of Visegrad group countries is relatively similar from the perspective of political instability, therefore they have similar potential of attracting FDI from this point of view.

Jáč and Vondráčková (2017) used survey and regression analysis for identification of factors affecting investment's location. This analysis aimed investors which invest in the Czech Republic. Investors are of the opinion that the tax system in the Czech Republic is too complicated (Jác and Vondráčková 2017). For the results of hypothesis focused on tax burden, they found that the level of tax burden does not have statistically significant effect on level of FDI (Jáč and Vondráčková 2017).

Taxation as an important part of business environment is also in the centre of interest of international organizations, like EU or OECD. Paper from Yoo (2003) deals with taxation of foreign investments in selected countries between years 1991 and 2001. As the measure was selected EATR developed by Devereaux and Griffith $(1999 ; 2003)$, Yoo (2003) selected effective tax rates for crossborder investment which calculation "results in a matrix of bilateral effective tax rates among OECD countries." (Yoo 2003) The results of effective marginal tax rates on inward FDI show that there was significant decrease of tax burden in 90s (Yoo 2003). There is relatively high tax burden on investments in Japan or USA. Effective tax burden of countries from Visegrad Group in 2001 were very competitive and often lower than of other OECD countries. On the other hand, every single bilateral relation is unique therefore should be evaluated individually. However, Ireland is the country, which provides lower tax burden for investors than other countries. Tax burden in Ireland is often lower by about 10 or more percentage points (Yoo 2003).

One of the European Commission's studies is from Elschner and Vanborren (2009) and shows overview of tax regimes in the EU and other developed countries. There is accented the comparison of old and new EU member states in this study. Results show that the tax burden in the EU is smaller than in countries like Japan or USA (Elschner and Vanborren 2009). For the tax competition within EU, it is important that the EATRs for the new member states are lower than these for old EU members are. (Elschner and Vanborren 2009). Another difference between these two groups of countries is related to types of assets when "in the old Member States, intangibles is the most tax-favoured asset, while for the new Member States it is machinery." (Elschner and Vanborren 2009) They have also analyzed development of tax burden in the EU between 1998 and 2007. EATRs have decreased in average across in all monitored countries but the lowering trend were stronger in new EU countries (Elschner and Vanborren 2009). For the Czech Republic, the effective tax burden used to be lower there than in countries with investments there, e.g. Germany.

Study from Bellak and Leibrecht (2009) focuses on effect of tax burden on the level of FDI. This study covers seven EU countries and USA for location of parent company and eight countries from Central and East Europe as host country with subsidiary. The aim was to find, if "a high corporate tax burden acts as a deterrent to FDI flows" (Bellak and Leibrecht 2009). The point of this hypothesis is that higher taxation make investments less profitable, so the companies try to maximize their investments profitability by minimizing tax liabilities. They used "generalized panel-gravity model with various location factors added." (Bellak and Leibrecht 2009) Dependent variable was "bilateral net-FDI-outflow in millions of euro from home country to" another concrete country (Bellak and Leibrecht 2009). It is important to mention that they used a bilateral effective average tax rate (BEATR), which assumes situation of the company from home country with subsidiary in certain country. For the results of its model, tax burden has an impact on investment size in particular country. For average, "a one percentage-point decrease in the effective tax rate increases net-FDI-outflows ceteris paribus by about 4.30\%." (Bellak and Leibrecht 2009) The decrease in the effective tax rate is related to BEATR, which assumes an investment of company from certain country to another host country. These results confirm the assumption, that tax burden is an important factor for business investment decision making. 
FDIs reaction on taxation in China has been an issue, which An (2012) studies. Concretely, he studies new corporate tax law in China, which is in force from 2008. This law has created similar taxation conditions for domestic and foreign corporations, mainly by termination of preferential tax treatment of foreign corporations (An 2012). His study is based on "a difference-in-differences approach" (An 2012). His paper aims reaction behavior of multinational companies, respectively their managers, and tried to find if this legislation changes results in decrease of foreign companies' investment activity in China. His results show the importance of level of taxation because foreign companies invest in lesser extent after mentioned legislation change (An 2012). There is more significant effect on corporations from Hong Kong, Macau and Taiwan (An 2012). This study confirms the importance of tax burden on level of investments in particular country. This article shows corporate tax burden differential as important factor for location of companies' investments.

When the special taxation condition is discussed, there must be mention the role of depreciation methods. Šimović and Žaja (2010) show that from the perspective of transition countries, accelerated depreciation can consider as effective way to provide tax incentives. Their study is focused on Balkan countries and two of them offered accelerated depreciation for the companies and also other countries provide beneficial depreciation regimes. Accelerated depreciation is considered also by Nuță and Nuță (2012) as an effective tool for attracting managers to invest in another country. From the perspective of accelerated depreciation, it is important how much tax reduction the advantage from the possibility of using it brings.

This paper focuses on countries from Visegrad Group. Further studies show that new EU countries have specific position when it comes to taxation. There arises one important question: how these countries stand against each other in terms of tax burden in 2018. The article aims differences in tax legislation related to cross-border investments in selected countries as position on market of tax competition. Further, the depreciation methods are analyzed as an important part of tax legislation, more concretely, this article looks at the situation of the depreciation legislation in the Czech Republic in more detail.

\section{Methodology}

Devereux and Griffith $(1999 ; 2003)$ model of EATR is selected as method for this study. Their approach assumes hypothetical investment of the company and includes the calculation of tax burden. They have developed formulas for several types of investments. Most importantly, they distinguish domestic investment and international investment. For addressing tax competition, the tax burden of international investment is important. They have introduced (as in the domestic case) effective marginal tax rate (EMTR) and EATR. This study is focused on calculation of EATRs for international investment. Some authors call them as bilateral effective average tax rate (BEATR) (Bellak and Leibrecht 2009) or EATR on FDI (Yoo 2003).

EATR for international investment is based on several assumptions, which has to be mentioned for the best interpretation of results. First of all, it assumes two types of companies, that resident in different countries (Devereux and Griffith, 2003). The first company is represented by "a parent firm located in the "home" country $j$ which undertakes investment in the "host" country n through a wholly-owned subsidiary." (Devereux and Griffith, 2003) Shareholders of parent company are from the same country $j$ as the firm. International corporations invest in different countries via subsidiaries and they transfer their profits with use of dividends to the parent company and shareholders. The calculation of EATR for international investment (BEATR) is shown by following formula (1) (Devereux and Griffith 2003):

$$
\operatorname{BEATR}_{n}=\frac{R_{n}^{*}-R_{n}}{E\left(1+\pi_{n}\right) p_{n} /(1+i)}
$$

For the expressions in (1): $\mathrm{R}_{\mathrm{n}}^{*}$ equals to the net present value (NPV) of the investment to the shareholders in the case of absence of taxation; $\mathrm{R}_{\mathrm{n}}$ stands for NPV in the case of taxation; $E$ stands for exchange rate; $\pi_{\mathrm{n}}$ represents inflation in the host country $n ; \mathrm{p}_{\mathrm{n}}$ equals to financial return; $i$ is nominal interest rate.

The NPV of the investment in the absence of taxation has relatively simple formula; all symbols from formula (2) has the same meaning as in formula (1) (Devereux and Griffith 1999; 2003): 


$$
R_{n}^{*}=\frac{\left\{E\left(1+\pi_{n}\right)\left(1+p_{n}\right)-(1+i)\right\}}{1+i}
$$

The calculation of NPV in case of taxation is more complicated. First of all, as it is in real economic environment, also Devereux and Griffith model assumes different types of financing the investment. There are three different sources, from which the company can cover the investment's costs: retained earnings $\left(\mathrm{R}_{\mathrm{n}}^{\mathrm{RE}}\right)$; new equity or new debt financing of parent company $(F)$; new equity or new debt financing of subsidiary $\left(\mathrm{F}_{\mathrm{n}}\right)$ (Devereux and Griffith 1999). Therefore, there is the following formula (3):

$$
R_{n}=R_{n}^{R E}+F+F_{n}
$$

Whereas the presence of taxation is considered in this section, there are several features of tax legislation which affect the NPV. First of all, there are statutory corporate tax rates for the home country $\left(\tau_{j}\right)$ and the host country $\left(\tau_{n}\right)$. There are also withholding tax rate on dividends, which pays the parent company $\left(c_{j}\right)$ and the subsidiary $\left(c_{n}\right)$. Term $\gamma$ is also associated with tax legislation and reflects "the tax discrimination between new equity and distributions"; $\gamma=\left(1-m_{d}\right)(1-c) /(1-z)(1-s)$, where $m_{d}$ stands for personal income tax rate levied on dividends; $c$ equals "the rate of tax credit available on dividends paid", $z$ "is the accruals-equivalent capital gains tax rate" and s "imputation credit on dividends received by the ultimate shareholder from the parent." (Devereux and Griffith, 1999, 2003). This measure is oriented on personal taxation in the home country of parent company where its shareholders are located. This parameter has the same value comparing the investments in two different countries, therefore this study assumes no personal taxation as it is done by Yoo (2003). Value of $\gamma$ is then set to unity.

When it is assumed a subsidiary in host country with parent company as owner in different country, the taxation of dividends has significant impact on NPV. Expression $\sigma_{\text {jn }}$ reflects actual tax rate related to dividend flows from subsidiary (in country j) to the parent company (in country $n$ ) (Devereux and Griffith 1999). This tax rate can have different values according to the tax legislation of country, see Table 1.

Table 1. Tax rate on dividends (Devereux and Griffith 1999; Yoo 2003).

\begin{tabular}{cc}
\hline$\sigma_{j n}=$ & Treatment of dividends payments \\
\hline$c_{n}$ & Exemption \\
$\max \left\{\frac{\tau_{j}-\tau_{n}}{1-\tau_{n}} ; c_{n}\right\}$ & Credit with limitation \\
$\tau_{j}\left(1-c_{n}\right)+c_{n}$ & Deduction \\
\hline
\end{tabular}

Whereas the parent company can lend to subsidiary, it results in interest payments. These interests are, of course, subject of taxation. Therefore there is expression $\omega_{j n}$, which represents "overall tax rate on interest payments from the subsidiary to the parent." (Devereux and Griffith 1999) This rate can have values from Table 2 , where is "withholding tax rate on interest payments made by the subsidiary ( $n$ ) to the parent" (Devereux and Griffith 1999).

Table 2. Tax rate on interests (Devereux and Griffith 1999; Yoo 2003).

\begin{tabular}{cc}
\hline $\boldsymbol{\omega}_{j n}=$ & Treatment of interests payments \\
\hline$\overline{\omega_{n}}-\tau_{n}$ & Exemption \\
$\max \left\{\tau_{j} ; \overline{\omega_{n}} ;\right\}-\tau_{n}$ & Credit with limitation \\
$\tau_{j}\left(1-\overline{\omega_{n}}\right)+\overline{\omega_{n}}-\tau_{n}$ & Deduction \\
\hline
\end{tabular}

The calculation - formula (4) - for "the economic rent generated by a perturbation in the capital stock financed by retained earnings" (Devereux and Griffith 2003):

$$
R_{n}^{R E}=\gamma\left(1-\sigma_{j n}\right)\left\{-\left(1-A_{n}\right)+\frac{E\left(1+\pi_{n}\right)\left\{\left(p_{n}+\delta\right)\left(1-\tau_{n}\right)+(1-\delta)\left(1-A_{n}\right)\right\}}{1+\rho}\right\}
$$


For not mentioned variables, $A_{n}$ stands for depreciation allowances, $\delta$ for economic depreciation rate and $\rho$ shareholder discount rate. In the case of FIFO method for valuation of inventories, the calculation has one modification shown in formula with assuming that exchange rate is unchanged during period (set as unity) (5) (Yoo 2003):

$$
R_{I N V}^{R E}=R_{n}^{R E}-\frac{\gamma_{j}(1-\sigma)}{(1+\rho)} \times \frac{\tau_{n} \pi_{n}}{\left(1-\tau_{n}\right)\left(1+\pi_{n}\right)}
$$

Calculation of depreciation allowances $\left(A_{n}\right)$ depends on tax legislation adjusting depreciation, which usually differs from one type of asset to another. Overall, there are two basic depreciation methods, which are commonly used in legislations: declining balance schedules and straight line schedules. Formula (6) for straight line depreciation.

$$
A_{S L}=\frac{\phi_{n} \tau_{n}\left(1+\rho_{n}\right)}{\rho_{n}}\left[1-\frac{1}{\left(1+\rho_{n}\right)^{N}}\right]
$$

In formula (6) $\phi \mathrm{n}$ is rate of tax depreciation, on stands for economic depreciation rate of selected asset and $\mathrm{N}$ represents period of tax depreciation. In the case of declining balance schedules, the formula is following - formula 7 (Yoo 2003):

$$
A_{D B}=\frac{\phi_{n} \tau_{n}\left(1+\rho_{n}\right)}{\phi+\rho_{n}}
$$

Different sources of financing result in different effects on tax burden. Therefore, this model takes into account financing strategy of the group. For the parent company, there are three different types of financing: by retained earnings, by new equity and by debt. Next Table 3 shows additional cost depending on source of financing.

Table 3. Additional rent depending on parent's source of finance (Devereux and Griffith 1999; Yoo 2003).

\begin{tabular}{cc}
\hline $\boldsymbol{F}=$ & Source of finance \\
\hline 0 & Retained earnings \\
$\frac{-\rho(1-\gamma)\left(1-\tau_{n} \phi_{n}\right)}{1+\rho}$ & New equity \\
$\frac{\gamma\left(1-\tau_{n} \phi_{n}\right)\left(\rho-i\left(1-\tau_{j}\right)\right)}{1+\rho}$ & Debt \\
\hline
\end{tabular}

The subsidiary can be in similar situation as the parent company. It can use for financing retained earnings, new equity (as the parent company decides) and debt from the parent company. Following Table 4 shows again the additional costs.

Table 4. Additional rent depending on subsidiary's source of finance (Devereux and Griffith 1999; Yoo 2003).

\begin{tabular}{cc}
\hline $\boldsymbol{F}_{n}=$ & Source of finance \\
\hline 0 & Retained earnings \\
$\frac{\gamma \sigma_{j n}}{(1+\rho)}\left(1-\tau_{n} \phi_{n}\right)[E-(1+\rho)]$ & New equity \\
$\frac{\gamma\left(1-\tau_{n} \phi_{n}\right)}{(1+\rho)}\left\{\sigma_{j n}\left[E\left(1+i\left(1-\tau_{n}\right)\right)-(1+\rho)\right]-E \omega_{j n} i\right\}$ & Debt \\
\hline
\end{tabular}

\section{Results}

Studies, which deal with EATR for cross-border investment, are originally based on similar assumptions. The assumptions for following calculations are presented in the Table 5 and 6 with addition that the investment is composed of $25 \%$ of the buildings, $25 \%$ of the machinery, $25 \%$ of the inventories, $12.5 \%$ of the patents and $12.5 \%$ of the software. For the rate of inflation, same value for all 
countries has been used (Yoo 2003) (Spengel et al. 2016). These economic parameters have the same value for every country because this study evaluate only the tax burden conditions, not economic conditions of selected countries. When it is used same values for these variables, the calculations are not affected by different economic conditions and describe the taxation conditions more clearly.

Table 5. Basic assumptions of calculations 1 (Yoo 2003; Spengel et al. 2016; OECD, 2017).

\begin{tabular}{cccc}
\hline Parametr & Symbol & Value & Background \\
\hline Rate of inflation & $\pi=\pi_{n}$ & $1.1 \%$ & Average OECD in 2016 (OECD, 2017) \\
Real interest rate & $r$ & $5 \%$ & Yoo (2003); Spengel et al. (2016) \\
Pre-tax rate of return & $p$ & $20 \%$ & Yoo (2003); Spengel et al. (2016) \\
\hline
\end{tabular}

Devereux and Griffith model of investment calculates with real (or true) economic depreciation of assets. This economic depreciation differs across selected assets because e.g. industrial building has longer expected life than transport equipment. Assuming economic depreciation rates are presented in following Table 6.

Table 6. Basic assumptions of calculations 2 (Spengel et al. 2016; OECD, 2017).

\begin{tabular}{ccc}
\hline Type of asset & $\begin{array}{c}\text { Rate of } \\
\text { economic } \\
\text { depreciation }\end{array}$ & Background \\
\hline Building & 0.0720 & Baldwin et al. (2005) \\
Machinery & 0.1750 & Spengel et al. (2016) \\
Patent & 0.1535 & Spengel et al. (2016) \\
Software & 0.3333 & Baldwin et al. (2005) \\
\hline
\end{tabular}

There has to be reviewed legislation of each of selected countries. This study covers countries from Visegrad Group as locations of investment. Depreciation methods used within countries and their corporate tax rates are presented in the Table 7.

Table 7. Depreciation and valuation of tangible assets in selected countries (EY 2018; PWC 2019; Getsix 2019).

\begin{tabular}{ccccccc}
\hline & Corporate income & \multicolumn{2}{c}{ Buildings depreciation } & \multicolumn{2}{c}{ Machinery depreciation } & Inventory \\
\hline Country & Statutory tax rate & SL rate & Period & SL rate & Period & Valuation \\
\hline CZE & 0.0720 & $1.4 \% / 3.4 \%$ & $1 / 29$ & $11 \% / 22.25 \%$ & $1 / 4$ & FIFO \\
HUN & 0.1750 & $3 \%$ & 33.33 & $14.5 \%$ & 6.9 & FIFO \\
POL & 0.1535 & $2.5 \%$ & 40 & $20 \%$ & 5 & LIFO \\
SVK & 0.3333 & $5 \%$ & 20 & $16.67 \%$ & 6 & Avg cost \\
\hline
\end{tabular}

There is one more option in the case of depreciation of assets in the Czech Republic. This option is called accelerated depreciation and is not one of the classical approaches to depreciation. On the other hand, the declining balance schedule has similar character as accelerated depreciation in the Czech Republic but the rate of depreciation is not the same in every year. Whereas this is a specific case of depreciation, the calculation of depreciation allowances has a specific formula (8) created on basis from Spengel et al. (2016):

$$
A_{A c c}=\phi_{1} \tau+\frac{\phi_{2} \tau}{1+\rho_{n}}+\frac{\phi_{3} \tau}{\left(1+\rho_{n}\right)^{2}}+\cdots+\frac{\phi_{N} \tau}{\left(1+\rho_{n}\right)^{N-1}}
$$

Every single year has its unique depreciation rate, therefore it cannot be expressed as it can be for straight line schedules in formula (6) and for declining balance schedules in formula (7). The first year's depreciation rate is calculated simply by dividing the one by number of years, when the asset can be depreciated. Depreciation rate for the following years can be expressed by following formula (9): 


$$
\phi_{n}=2\left(1-\sum_{i=1}^{n-1} \phi_{i}\right) * \frac{1}{N-n+1}
$$

This study also considers the investment into intangible assets; presented by software and patent. Table 8 shows the tax depreciation of these assets in selected countries. The situation in Slovakia is complicated because there are no rules for tax depreciation of intangible assets. Within the calculations it is expected that the depreciation for tax purposes corresponds with economic depreciation of assets.

Table 8. Depreciation of intangible assets in selected countries (EY 2018; PWC 2019; Getsix 2019).

\begin{tabular}{ccccccc}
\hline & \multicolumn{3}{c}{ Software depreciation } & \multicolumn{3}{c}{ Patents depreciation } \\
\hline Country & Method & Rate & Period & Method & Rate & Period \\
\hline CZE & SL & $33.33 \%$ & 3 & SL & $16.67 \%$ & 6 \\
HUN & SL & $50 \%$ & 2 & SL & $50 \%$ & 2 \\
POL & SL & $50 \%$ & 2 & SL & $20 \%$ & 5 \\
SVK & In line with accounting depreciation & In line with accounting depreciation \\
\hline
\end{tabular}

There were selected four countries, which represent home countries of parent companies: Austria, Germany, Luxembourg and Netherlands. This choice is consistent with the biggest amounts of FDI in the Czech Republic presented by country of origin ( $\check{C} \mathrm{NB}, 2017)$ and also with other historical amounts of FDIs in all V4 countries because the four selected countries belong to the biggest investors in Visegrad Group (UNCTAD, 2018). Treatment of dividends is shown in Table 9.

Table 9. Dividends treatment and tax rates in selected "home" countries (EY 2018).

\begin{tabular}{cccccc}
\hline Country & Treatment & CZE & HUN & POL & SVK \\
\hline AUT & Exemption & $0 \%$ & $10 \%$ & $5 \%$ & $10 \%$ \\
GER & $95 \%$ exemption & $0 \%$ & $0 \%$ & $0 \%$ & $0 \%$ \\
LUX & Exemption & $0 \%$ & $0 \%$ & $0 \%$ & $0 \%$ \\
NED & Exemption & $0 \%$ & $0 \%$ & $0 \%$ & $0 \%$ \\
\hline
\end{tabular}

For the treatment of interest payments, all countries use credit. The most of the bilateral relation has $0 \%$ tax rate levied on interest payments. (EY 2018) The 5\% tax rate is levied only on interest flows from Poland to Germany or Austria. Statutory corporate tax rates are the last tax legislation feature, which is included in calculation. Corporate tax rates are following: $25 \%$ in Austria, 30\% in Germany, $26.01 \%$ in Luxembourg and 25\% in Netherlands (KPMG 2019). It is important to mention that tax rates in Germany and in Luxembourg depends on the location, so the rate is not applicable on all situations. Furthermore, there is progressive taxation in Netherlands and in Luxembourg. In case of the Netherlands, the higher from the rates is applied.

First calculation within this study is EATR for cross-border investment in the Czech Republic in the case of different selection of depreciation methods. This calculation compares two cases: one with selection of classic straight line depreciation method and the second with use of accelerated depreciation. BEATR is calculated for all four selected home countries of parent company and the results are presented in Figure 1. 


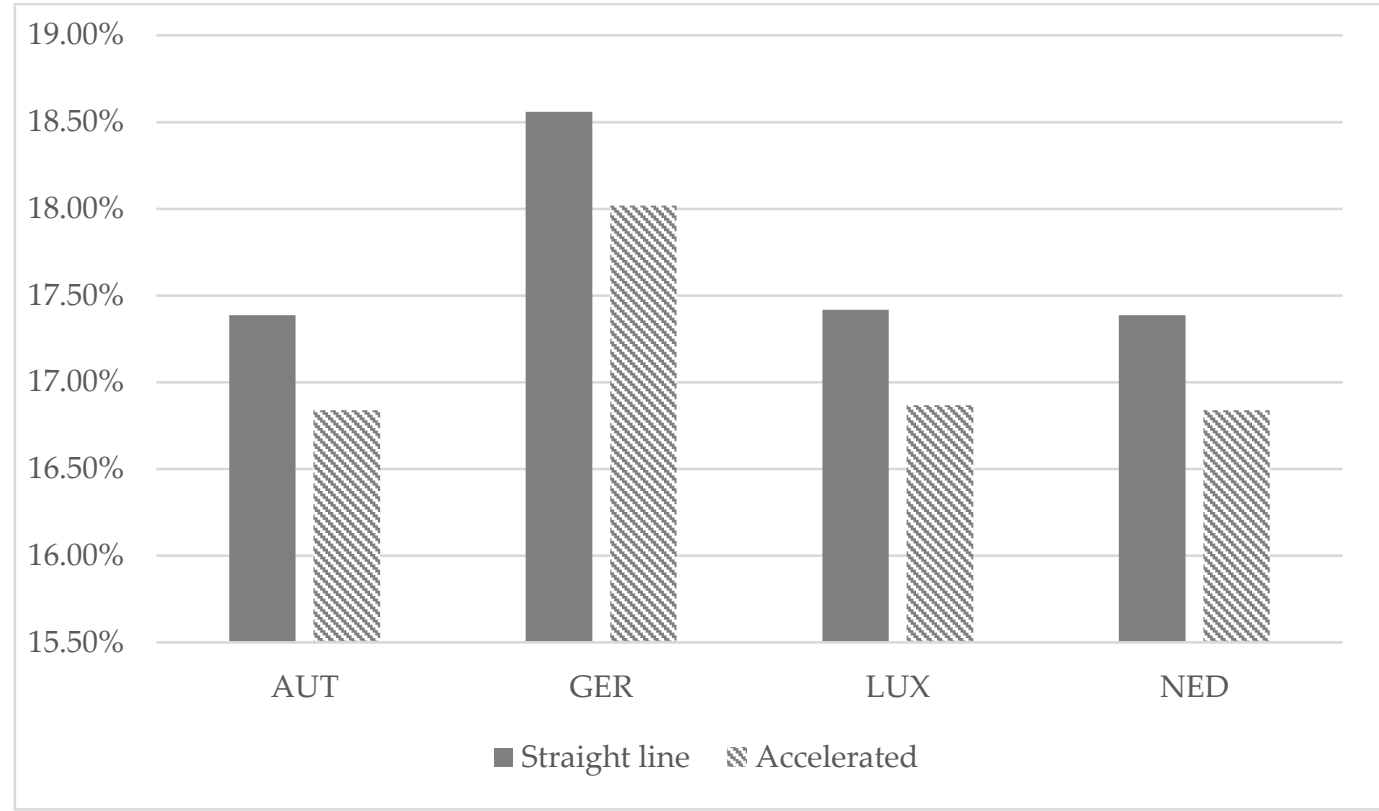

Figure 1. Comparison of depreciation methods' effects on EATRs in the Czech Republic.

Previous graph shows that the selection of depreciation method has significant impact on effective tax burden of the investment. Use of accelerated depreciation method for tax purposes decrease BEATR by about a half percentage point. Accelerated depreciation brings an advantage in time value of money. Whereas the accelerated method allows high tax depreciation in first years when the time value of money is higher than in following years, the effective tax burden considering Devereux and Griffith model is lower. This case of the Czech Republic shows the importance of depreciation methods for company taxation. Legislation in the Czech Republic is the only one within Visegrad Group, which brings choice of depreciation method for the companies. The results of calculations for every bilateral relation which follows methodology from Devereux and Griffith are presented in Table 10.

Table 9. Dividends treatment and tax rates in selected "home" countries.

\begin{tabular}{ccccc}
\hline Country & AUT & GER & LUX & NED \\
\hline CZE ACC & $16.84 \%$ & $18.02 \%$ & $16.87 \%$ & $16.84 \%$ \\
CZE SL & $17.39 \%$ & $18.56 \%$ & $17.42 \%$ & $17.39 \%$ \\
HUN & $16.26 \%$ & $9.85 \%$ & $8.57 \%$ & $8.54 \%$ \\
POL & $20.47 \%$ & $18.22 \%$ & $17.08 \%$ & $17.05 \%$ \\
SVK & $25.19 \%$ & $19.63 \%$ & $18.50 \%$ & $18.47 \%$ \\
\hline
\end{tabular}

The results of cross border EATR for selected countries show that Hungary's legislation offer the lowest effective tax burden for all locations of the parent company. EATR for Hungary in the cases of location of parent company in Germany, Luxembourg and Netherlands is half opposite to the situations for investment in other countries. In the case of investment from Austria, Hungary still leads the Visegrad Group but the difference between BEATR in the Czech Republic and in Hungary is about 0.6 percentage point. The highest effective tax burden is in Slovakia, where the value of BEATR is the least advantageous in all monitored cases. Overall, the Czech Republic offer better conditions than Poland and Slovakia but there is a lot higher effective tax burden comparing to Hungary.

\section{Discussion}

The huge gap in BEATRs between Hungary and other countries is caused by 2017's reduction of statutory corporate tax rate. The rate for 2016 in Hungary were at 19\%, which is the same rate that is currently in the Czech Republic. According to results from Spengel et al. (2016), the Czech Republic offered better taxation condition than Hungary in 2016. Legislation change in Hungary has caused this difference and Hungary has become the country with the lowest effective tax burden in this area. 
Almost identical value of BEATRs for investment from Austria to Hungary and to the Czech Republic is caused by different treatment of dividend payments to home country of parent company. These values show the importance of tax treaties between countries. Dividend payments from Hungary to Austria are taxed by $10 \%$; on the other hand, the same payments from the Czech Republic are not subject of taxation. Similar effect applies to other two countries: Poland and Slovakia. The Czech Republic has the best position in Visegrad according to tax treaties because none of the crossborder payments are subject of taxation. Despite this advantage, even in the case of investment from Austria is the Czech BEATR higher than value for Hungary.

Position of Hungary within the tax competition is even better than it is shown by the Table 10 . Some companies can benefit from IP (intellectual property) box, which rests in $50 \%$ deduction (Koka and Kocsis 2016). For this purposes the company has to follow the legislation and this tax regime can be used only for qualified income and qualified expenditures. Basically, it addresses company's own IP activities. Hungary's orientation on IP demonstrates also depreciation legislation dealing with intangible assets. The depreciation there is the quickest in the range of Visegrad Group countries, what also affects the tax burden. Despite the stricter legislation, which is now connected with IP boxes tax advantage can be for certain group of companies significant (Jedlička 2018).

According to the depreciation methods, their importance is documented by Figure 1 and Table 10. The legislation in the Czech Republic offers two methods, from which the accelerated one is the better choice for lower tax burden. It is important to mention that the half percentage point difference is calculated for the case of combined investment which is in line with previous research demonstrating the importance of accelerated depreciation (Šimović and Žaja 2010); (Nuţă and Nuță 2012). The change of depreciation method has effect only on half of investment (for buildings and machinery). The real difference counting only with one asset is almost one and half percentage points for buildings, according to intermediate calculations. The ability of using an accelerated depreciation in the Czech Republic is also the reason of better results of BEATR then for Poland. Statutory corporate tax rate is the same in both countries (19\%) therefore the different tax burden is associated with depreciation methods and tax treaties. Standard straight line depreciation method in the Czech Republic is less beneficial than the one in Poland and the BEATRs with using SL method is higher for the Czech Republic (it is not the case of Austria as parent's location due to different treatment of dividend payments).

There is one more view, which is important to consider when the results are discussed. The legislations of countries, from which the investment come, are also important for tax burden. In this case, results show that Netherlands and Luxembourg offer the best conditions as for parent companies. Netherlands and Luxembourg are considered as tax havens and multinationals often reside there (Berkhout 2016). Therefore huge amount of investments flows from these two countries into Visegrad Group. Globalisation causes that for example originally German company can have residence in Netherlands and invests in the Czech Republic. The multinational company makes not only the decision, where to invest, but also where to set the location of parent company.

Used method has some limitation because it is based on the tax legislation. There are also used special contracts between investors and governments which similar method cannot cover. These tax incentives cannot be integrated into used model and therefore the BEATRs reflects only regular conditions for investment in certain country. Further studies can focus on effects of taxation policy on real investment activity of multinationals with analysis of the importance of tax burden on investments in Visegrad Group. Countries of Visegrad group have relatively similar legislation but there are several differences which can play a key role in selection of investment's location. The depreciation method is one of the most important factors, which significantly influences tax burden and can have large impact within the tax competition. For better understanding of investment activities in this area, focusing on situation in different industries would be also beneficial. 


\section{Conclusions}

This paper documents the differences between tax burdens of investments in different countries of Visegrad Group. Within this union, Hungary offers the best conditions for cross-border investments. Their legislation is also the one most targeting intangible assets and also offers preferential tax regime for intellectual property activities. The Czech Republic has the most beneficial tax treaties in Visegrad Group. Tax treaties has been played a key role and still there are some differences. On the other hand, tax treaties between the countries from the EU offer usually similar conditions in different locations.

Legislation of the Czech Republic is unique for the availability of two depreciation methods for tax purposes. Findings related to depreciation conditions in the Czech Republic are very important in current situation of tax burden in selected countries. Whereas the treatment of cross-border payments tend to be similar, the reduction or increase of tax burden can be made, besides changing statutory corporate tax rate, also by change of depreciation methods. Financial managers should monitor changes in legislation not only from the perspective of tax rates but also consider the effects of the depreciation on taxation.

\section{References}

An Zhiyong. 2012. Taxation and foreign direct investment (FDI): empirical evidence from a quasi-experiment in China. International tax and public finance: 19(5), 660-676. https://doi.org/10.1007/s10797-011-9201-0.

Baldwin John, Gellatly Guy, Tanguay Marc, and Patry André. 2005. Estimating depreciation rates for the productivity accounts. OECD Workshop on Productivity Measurement: October. Available online: http://search.oecd.org/sdd/productivity-stats/35409605.pdf (accessed on 23 January 2019).

Bellak Christian, and Leibrecht Markus. 2009. Do low corporate income tax rates attract FDI?-Evidence from Central-and East European countries. Applied Economics: 41(21), 2691-2703. https://doi.org/10.1080/00036840701320217.

Berkhout Esmé. 2016. Tax Battles: The dangerous global race to the bottom on corporate tax. Oxfam international. Oxford: Oxfam GB. Available online: https://www.oxfam.org/en/research/tax-battles-dangerous-globalrace-bottom-corporate-tax (accessed on 21 March 2019).

ČNB. 2017. Přímé zahraniční investice. 3.1. STAV Pर̌ÍMÝCH ZAHRANIČNÍCH INVESTIC V ČESKÉ REPUBLICE k 31.12.. Available online: https://www.cnb.cz/analytics/saw.dll?Portal (accessed on 31 August 2017).

Devereux P. Michael, and Griffith Rachel. 2003. Evaluating tax policy for location decisions. International Tax and Public Finance: 10(2), 107-126. https://doi.org/10.1023/A:1023364421914.

Devereux P. Michael, and Griffith Rachel. 1999. The taxation of discrete investment choices. IFS working papers: No. W98/16. London: Institute for Fiscal Studies. Available online: https://discovery.ucl.ac.uk/id/eprint/14909/1/14909.pdf (accessed on 31 August 2017).

Elschner Christina, and Vanborren Werner. 2009. Corporate effective tax rates in an enlarged European Union. Luxembourg: European Commission.

EY. 2018. Worldwide Corporate Tax Guide 2018. Available online: https://www.ey.com/Publication/vwLUAssets/EY_Worldwide_Corporate_Tax_Guide_2018/\%24File/EY-

2018-worldwide-corporate-tax-guide.pdf (accessed on 29 January 2019).

Getsix. 2019. Business Taxation in Poland. Available online: http://getsix.eu/resources/doing-business-inpoland/business-taxation-in-poland/ (accessed on 29 January 2019).

Jáč Ivan, and Vondráčková Marie. 2017. The perception of selected aspects of investment attractiveness by businesses making investments in the Czech Republic. E+M Ekonomie a Management: 20(3), 118-132. https://dx.doi.org/10.15240/tul/001/2017-3-008.

Jedlička Vít. 2018. Tax Competition and IP Boxes after the Application of the Modified Nexus Approach. Journal of Competitiveness: 10(4), 70-84. https://doi.org/10.7441/joc.2018.04.05.

Koka Gabor, and Kocsis Gabriella. 2016. New IP regime in Hungary. Available online: https://www.expertguides.com/articles/new-ip-regime-in-hungary/arrgbfql (accessed on 2 September 2017).

KPMG. 2019. Corporate tax rate table. Available online: https://home.kpmg.com/xx/en/home/services/tax/taxtools-and-resources/tax-rates-online/corporate-tax-rates-table.html (accessed on 29 January 2019).

Mádr Michal, and Kouba Luděk. 2014. Politická nestabilita a př́liv přímých zahraničních investic v tranzitivních ekonomikách. Political instability and inflows of foreign direct investment in transition countries. Scientific Papers of the University of Pardubice, Series D: 21(32), 85-97. 
Nuţă Alina Cristina, and Nuţă Florian Marcel. 2012. The effectiveness of the tax incentives on foreign direct investments. Journal of Public Administration, Finance and Law: 1(1), 55-65.

OECD. 2017. Inflation (CPI) (indicator). Available online: https://data.oecd.org/price/inflation-cpi.htm (accessed on 31 August 2017).

PWC. 2019. Worldwide Tax Summaries. Available online: http://taxsummaries.pwc.com/ID/tax-summaries-home (accessed on 29 January 2019).

Šimović Hrvoje, and Mihelja Žaja Maja. 2010. Tax Incentives in Western Balkan Countries. International Journal of Social, Education, Economics and Management Engineering: 4(6), 111-116.

Spengel Christoph. 2016. Effective tax levels using the Devereux/Griffith methodology. Project for the EU Commission TAXUD/2013/CC/120: Final report. Mannheim: ZEW-Gutachten und Forschungsberichte.

UNCTAD. 2018. Bilateral FDI Statistics. Available online: https:/unctad.org/en/Pages/DIAE/FDI\%20Statistics/FDI-Statistics-Bilateral.aspx (accessed on 29 January 2019).

Yoo Kwang-Yeol. 2003. Corporate Taxation of Foreign Direct Investment Income 1991-2001. OECD Economics Department Working Papers: No. 365. Paris: OECD Publishing. Available online: https://pdfs.semanticscholar.org/f725/129a82f4a8f13d408a1977869a34799559b4.pdf (accessed on 31 August 2017). 